\title{
Effect of wood shaving litter density on the growth, leg disorders and manurial value in broiler
}

\author{
MA Hossain ${ }^{1 *}$, I Zulkifili², S Islam³ and EA Awad ${ }^{2}$
}

${ }^{1}$ Department of Dairy and Poultry Science, Chittagong Veterinary and Animal Sciences University, Khulshi, Chittagong-4225, Bangladesh; ${ }^{2}$ Institute of Tropical Agriculture \& Food Security, UPM, Serdang, Malaysia; ${ }^{3}$ Department of Animal Science and Nutrition, Bangabandhu Sheikh Mujibur Rahman Agricultural University, Salna, Gazipur-1706, Bangladesh

\begin{abstract}
The study was conducted with an aim to investigate the effect of litter density on growth, leg health and litter quality of broiler chickens from d1-42 days. Day-old male broiler chicks $(n=400$; Cobb 500) were distributed randomly into four litter densities $\left[T_{1}, T_{2}, T_{3}\right.$ and $\left.T_{4}\right]$ treatments, each treatment had 5 replicates with 20 birds per replicate cage in a completely randomized design. Wood shaving was used as litter materials to a thickness of $5 \mathrm{~cm}, 8 \mathrm{~cm}, 11 \mathrm{~cm}$ and $14 \mathrm{~cm}$ on the floor of the pen. Birds were reared on the litter floor open-sided housing condition with ad libitum feed and water throughout the trail period. Data on feed intake (FI), body weight (BW), feed conversion ratio (FCR) and mortality were measured weekly. Litter sample was collected on day 42 to assess the nitrogen content $\left(\mathrm{N}_{2} \%\right)$, dry matter (DM\%) and moisture level (\%). Footpad dermatitis (FPD) and hock burn (HB) incidences were measured on day 42 to assess the leg quality of birds. Results demonstrated that litter thickness had no significant $(P>0.05)$ effect on FI, BW, FCR and mortality of broilers from d1-42 days. The $\mathrm{N}_{2}, \mathrm{DM}$ or moisture levels $(\%)$ of litter were also unaffected $(P>0.05)$ between treatment. Leg disorders such as $\mathrm{HB}$ and FPD were influenced $(\mathrm{P}<0.01)$ by treatment. The incidences of HB and FPD were higher $(P<0.01)$ in $T_{1}$ and $T_{2}$ than other treatments. It can be inferred from our current study that, leg health may be deteriorated by using low density wood shaving without affecting growth and litter quality of broiler chickens.
\end{abstract}

Key words: growth, footpad dermatitis, hock burn, litter thickness and composition, wood shaving, chicken

Bangladesh Animal Husbandry Association. All rights reserved.

Bang. J. Anim. Sci. 2018. 47 (1):21-27

\section{Introduction}

Litter or bedding material is used in the poultry house to provide comfortable environmental condition as well as to achieve optimum productive performances. It is clear that broiler performance depends on many factors such as chick quality, flock uniformity, bird size, nutrition and live weight on their first day of life including others (Cervantes, 1994; Decuypere et al., 2001). Apart from these, litter material is another important factor, which can contribute better production potentiality for poultry (Hossain et al., 20013). Birds can confront many challenges if they are raised on the litter floor. Litter material determines chickens' skin condition, which might influence the incidence of injuries as well as the conditions of the environment where birds are reared. Further, litter might cause carcass, breast, skin and leg lesions or injuries, as the birds are reared on the litter floor, and come directly into the close contact of the litter materials. Besides, litter might harbour many infectious agents such as coccidia, which might affect the production performance of the broilers. Some litter materials can contain high moisture or humidity levels which might also aggravate the occurrence of lesions, mainly on chicken breasts and footpads (Zavala, 1997; Willis et al., 1997; Godwin et al., 2000). Apart from nutrition, the major factors leading to foot-pad dermatitis seem to be related to the litter moisture and excreta adherence to the skin. These challenges of using litter in poultry production can cause financial losses to the growers due to total or partial condemnation of carcasses, reduction in the price of the final product and reduction in the speed of processing (Oliveira et al., 2002).

The prevalence of leg problems of broiler chickens could be affected by a numerous factors, including litter quality, feed sources, nutrient density, dietary protein levels,

*Corresponding author: mhossainmu@yahoo.com 
deficiency of specific nutrients, especially vitamins and minerals in broiler diets (Bilgili et al., 2006; Brickett et al., 2007). However, the incidence and severity of leg problems that is faced by the fast growing meat chickens is of great concern to the poultry enterprise, in terms of product quality and animal well-being viewpoint. Birds with increased number of leg problems are culled from the flock or downgraded at slaughter (Kestin et al., 1999). Weak bones result in breaking during processing and lower meat grade. Also weak legs often result in reduced feed intake thus affecting weight gain as well as product quality (Orban et al., 1999).

Wood shavings are a good litter, and are commonly used as bedding material in broiler production all over the world including Bangladesh. The aim of using good litter material in broiler production is, to prevent the direct contact of the bird with the floor and to promote the absorption of the faecal moisture (Garcia et al., 2010). Many materials have been already examined as alternatives to replace wood shavings as litter materials (Reed \& McCartney, 1970; Parsons \& Baker, 1985; Santos et al., 2000). However, various litter such as sawdust, sugarcane bagasse, rice husk, wheat straw, sand and ash are used as poultry bedding. It is reported that very few research work on the depth of litter material is done on the growth performance, leg heath and litter quality of broilers. With those idea in view, the present study is undertaken to find out the suitable density of wood shaving as litter material for profitable broiler production.

\section{Materials and Methods}

\section{Bird management and experimental design}

A total of 400 (Cobb500) day-old male broiler chicks was procured from the local hatchery. The chicks were weighed on receipt and then assigned randomly in groups of 20 to 20 floor pens with wood-shavings as litter material. Birds were reared in a floored pen, open- housing condition from $\mathrm{d} 1$ to 42 days on the different densities of wood shavings $(5 \mathrm{~cm}, 8$ $\mathrm{cm}, 11 \mathrm{~cm}$ and $14 \mathrm{~cm}$ ). Each treatment had five replicate pens, 20 birds per replicate in a CRD design, as shown in Table 1 . Chicks were brooded with a with a temperature of $33{ }^{\circ} \mathrm{C}$ for the first two days of rearing period. The temperature was then gradually reduced by 1 or $2{ }^{\circ} \mathrm{C}$ every 1 or 2 days until the chicks were 19 days old at which point the temperature was maintained at $24^{\circ} \mathrm{C}$ for the rest of the trial. Continuous lighting program was maintained entire the trial period. Feed was provided ad libitum in mash form and birds had a free access to water all the time until the last day of rearing birds. In the first 3 weeks, the birds were given starter diets followed by the finisher diets for the last 3 weeks. All the diets were isocaloric and iso-nitrogenous, as shown below in Table 2.

\section{Data collection}

Prior to feeding, chicks were weighed at the first day of starting trial. Live weight, feed consumption and feed conversions ratios were calculated weekly. Mortality was recorded when it occurred. Litter samples from each replicate cage were collected on day 42 to measure out nitrogen $\left(\mathrm{N}_{2}\right)$, dry matter (DM) and moisture content. Hock burn and footpad dermatitis incidences of birds were also assessed on day 42 to assess the leg quality of broiler chickens.

\section{Measuring of Hock burn (HB) and Foot pad dermatitis (FPD)}

"Hock burn" (HB), is closely related to FPD, in which the skin of the hock becomes dark brown. In severe cases, scabs are observed. A total of 10 birds were randomly selected from each replicate cage, and observed the HB of each birds visually for any incidence of dermatitis or disorder, wound, lesions, and scored against a number of criteria. The hocks were given 1 (not affected), 2 (colour changes or minor lesions), or 3 points (severe lesions). Left and right hocks were scored separately.

Table 1. Experimental design

\begin{tabular}{lrrrrr}
\hline Replicates & \multicolumn{2}{c}{ Treatments } & \multicolumn{2}{c}{ Total } \\
\cline { 2 - 5 } & $\mathbf{T}_{\mathbf{1}}$ & $\mathbf{T}_{\mathbf{2}}$ & $\mathbf{T}_{\mathbf{3}}$ & $\mathbf{T}_{\mathbf{4}}$ \\
\hline $\mathrm{R}_{1}$ & 20 & 20 & 20 & 20 & 80 \\
$\mathrm{R}_{2}$ & 20 & 20 & 20 & 20 & 80 \\
$\mathrm{R}_{3}$ & 20 & 20 & 20 & 20 & 80 \\
$\mathrm{R}_{4}$ & 20 & 20 & 20 & 20 & 80 \\
$\mathrm{R}_{5}$ & 20 & 20 & 20 & $\mathbf{1 0 0}$ & 80 \\
Total & $\mathbf{1 0 0}$ & $\mathbf{1 0 0}$ & $\mathbf{1 0 0}$ & $\mathbf{4 0 0}$ \\
\hline
\end{tabular}

$T_{1}$ refers to litter density of $5 \mathrm{~cm}$, whereas $T_{2}, T_{3}$ and $T_{4}$ treatments indicate 8,11 and $14 \mathrm{~cm}$, respectively. 
Hossain et al. (2018) Bang. J. Anim. Sci. 47 (1):21-27

Table 2. Ingredient and nutrient composition of the basal diet

\begin{tabular}{lcc}
\hline Ingredients (\%) & \multicolumn{2}{c}{ Diets } \\
\cline { 2 - 3 } & Starter (d1-21) & Finisher (d22-42) \\
\hline Corn & 57.77 & 61.50 \\
Soybean meal & 34.58 & 30.00 \\
Palm oil & 3.60 & 5.20 \\
DCP & 1.68 & 1.35 \\
Limestone & 1.15 & 1.00 \\
Table salt & 0.40 & 0.38 \\
Choline Cl-70\% & 0.05 & 0.08 \\
Vita- premix & 0.05 & 0.05 \\
Min- premix & 0.10 & 0.10 \\
L-lysine & 0.34 & 0.16 \\
DL-methionine & 0.19 & 0.15 \\
L-Threonine & 0.09 & 0.03 \\
Total & 100 & 100 \\
Nutrient composition (\%) & & \\
ME (MJ/kg) & 12.71 & 13.32 \\
Crude protein & 21.02 & 19.01 \\
Calcium & 0.91 & 0.76 \\
Average Phosphate & 0.45 & 0.38 \\
Mysine & 1.18 & 0.95 \\
Threthionine & 0.45 & 0.40 \\
\end{tabular}

\section{Method of scoring the incidence of FPD of} broilers

FPD is a type of contact dermatitis affecting the plantar region of the feet in poultry and other birds. At an early stage, discoloration of the skin is seen. Hyperkeratosis and necrosis of the epidermis can develop, and in severe cases, these changes are followed by ulcerations with inflammatory reactions of the subcutaneous tissue (Ekstrand et al., 1997). The severity and incidence of FPD of broilers are scored by visual ranking system on day 42 . The FPD scoring test followed the 3-point scoring system developed by Nagaraj et al. (2007). To conduct the test, 10 birds were randomly selected from each replicate cage, and observed the foot-pad of each birds visually for any incidence of dermatitis or disorder, wound, lesions and scored against a number of criteria accordingly (Table 3).

\section{Statistical analyses}

Statistical analyses were performed using Minitab software (Minitab Version 16, 2000). The data were analyzed using a one-way ANOVA with litter density as independent factor. The significance of difference between means was determined by Fisher's least significant difference at $P \leq 0.05$.

\section{Results}

The gross responses of broilers in terms of feed intake, live weight gain, feed conversion ratio (FCR) and mortality on the different density of litter materials are shown in Table 4. It indicates that litter thickness had no significant $(P>0.05)$ effect on the gross responses of broiler chickens, as is shown in the Table 4.

Table 3. Three point scoring system of foot-pad dermatitis of broiler chickens

\begin{tabular}{cll}
\hline Scores & Degree of impairment & \multicolumn{1}{c}{ Criteria } \\
\hline 1 & Foot-paw with no lesion & $\begin{array}{l}\text { Dermal ridges intact within central plantar footpad surface, with } \\
\text { or without discoloration; }\end{array}$ \\
2 & $\begin{array}{l}\text { Footpads with mild } \\
\text { lesions }\end{array}$ & $\begin{array}{l}\text { Dermal ridges not intact within a central, round to oval ulcer on } \\
\text { the central plantar footpad surface, roughened lesion surface } \\
\text { with small tag of crust less than } 1.5 \mathrm{~cm} \text { in diameter; }\end{array}$ \\
3 & $\begin{array}{l}\text { Footpads with severe } \\
\text { lesions }\end{array}$ & $\begin{array}{l}\text { A brown crust more than } 1.5 \mathrm{~cm} \text { in diameter, adhered to the } \\
\text { central plantar footpad, sometimes extending up to the hock } \\
\text { joint }\end{array}$ \\
\hline
\end{tabular}


Litter composition (Nitrogen percentage, dry matter and moisture level) was also unaffected $(P>0.05)$ between treatment (Table 5$)$. Litter density had no impact $(P>0.05)$ on the manurial value of wood shavings between treatment (Table 5). Only hock burn (HB) and foot pad dermatitis (FPD) scores were significantly $(P<0.01)$ affected by treatment (Figure 1$)$. Higher incidences $(P<0.01)$ of $\mathrm{HB}$ and FPD were observed in the broiler chickens reared on lower density litter material $\left(T_{1}\right.$ and $T_{2}$ ) than those reared on higher density ( $T_{3}$ and $\mathrm{T}_{4}$ ) litter materials (Figure 1 ). The higher scores of $H B$ and $F P D$ were found in $T_{1}$ and $T_{2}$ treatments whereas $T_{3}$ and $T_{4}$ treatment being the lowest scores in HB and FPD.

\section{Discussion}

From the current study it is clear that, the gross response of broiler chickens raised on the different density of litter material (wood shaving) was not affected. It implies that litter density had a similar impact on the growth performances of the broiler chickens. Our result could be in agreement with the previous investigators (Haque and Chowdhury, 1994; Mizuet al., 1998; Anisuzzaman and Chowdhury, 1996), who observed similar responses when different depths $(2.0,3.0,4.0$ and $5.0 \mathrm{~cm})$ of rice husk were used for broiler production.

Broiler litter composition such as nitrogen content, dry matter and moisture levels also were not influenced by the different density of litter materials, as is evinced from our current study. It indicates that manurial value of the supplied litter was identical. The litter can be used in the land as organic manure for increasing soil fertility as well as to reduce the burden of excess application of chemical fertilizer on the crop fields. From this result, it can be postulated that litter composition could be similar, if different density of single litter matter is used for production of broiler chickens. However, many dietary factors such as protein level, electrolytic balance, ionophores, cereal contents, fibre content, legumes and NSPs etc., might regulate the excreta /litter moisture and quality (Fleet and Saylor, 1983; Smith et al., 2000; Murakami et al., 2001, Francesch and Brufau, 2004). The scores of foot health are being imposed to control the broiler health and welfare in the European countries such as Sweden and Denmark (Kjaer et al., 2006). So the incidence and severity of leg problems that is faced by the broilers is of great concern to the poultry enterprise, in terms of product quality and animal welfare (Hossain et al., 2013a). Culling rate and downgrading carcasses during slaughter period are increased with the increase number of leg problems encountered in broilers (Kestin et al., 1999).

Litter density influenced the leg health significantly as is observed from our current research findings. The results revealed that the incidence of leg disorders such as HB and FPD was found to be increased in the broilers raised on low density litter material (wood shavings) compared to high density litter matter (wood shavings). The reason behind this incidences could be the thickness, absorbability and moisture level of the supplied litter material i.e, wood shaving supplied to the broiler chickens. As it is reported that, the excess moisture could affect the litter quality adversely and leads to an increased risk of development of footpad dermatitis and other disease incidences (Hossain et al., 2013a).

Many previous investigators reported that some litter materials having increased moisture levels, could also enhance the occurrence of lesions, mainly on chicken breasts and footpads (Zavala, 1997; Willis et al., 1997; Godwin et al., 2000). Moreover, the incidence and severity of FPD and HB could be increased, if any factors that increase bird water excretion and excreta viscosity (Eichneret al., 2007). Though the moisture level difference between treatment was insignificant in our present study, the high density litter had a comparatively lower moisture level than the low density litter. Further, wood shavings act as a good absorbent litter materials in poultry rearing. So it can be assumed that high density wood shavings could have more absorption capacity of moisture and reduced humidity than the low density litter matter, and this properties of the litter materials might influence the frequency of leg disorders (HB, FPD) or leg problem of the broiler chickens. Further, any dietary change that increases water intake of birds will lead to an increase in excreta moisture level. The NSP contents of plant diets arising from soybean and other meals could affect digestion of other nutrients by attracting water and contributing to higher litter moisture (Francessch and Brufau, 2004). 
Table 4. Feed intake, live weight gain, feed conversion ratio (FCR) and mortality of birds raised on different densities of litter material (wood shaving) from d1-42 days

\begin{tabular}{|c|c|c|c|c|c|c|c|}
\hline \multirow[t]{2}{*}{ Parameters } & \multirow[b]{2}{*}{$\begin{array}{l}\text { Age } \\
\text { (days) }\end{array}$} & \multicolumn{4}{|c|}{ Treatment } & \multirow[b]{2}{*}{ Pooled SEM } & \multirow[b]{2}{*}{ P-values } \\
\hline & & $\mathbf{T}_{1}$ & $\mathbf{T}_{\mathbf{2}}$ & $\mathbf{T}_{3}$ & $\mathbf{T}_{4}$ & & \\
\hline \multirow{3}{*}{$\begin{array}{l}\text { Feed intake } \\
\qquad(\mathrm{g} / \mathrm{b})\end{array}$} & $1--7$ & 120.30 & 117.81 & 123.96 & 123.20 & 2.350 & 0.782 \\
\hline & $1-21$ & 1172.80 & 1165.30 & 1169.10 & 1187.90 & 7.804 & 0.751 \\
\hline & $1-35$ & 3205.50 & 3237.50 & 3243.20 & 3256.00 & 16.547 & 0.741 \\
\hline \multirow{5}{*}{$\begin{array}{l}\text { Live weight gain } \\
\qquad(\mathrm{g} / \mathrm{b})\end{array}$} & $1-42$ & 4434.30 & 4514.60 & 4548.90 & 4463.20 & 68.739 & 0.935 \\
\hline & $1--7$ & 113.01 & 114.00 & 112.00 & 116.74 & 0.048 & 0.753 \\
\hline & $1-21$ & 878.20 & 883.83 & 889.50 & 891.66 & 7.580 & 0.922 \\
\hline & $1-35$ & 2053.80 & 2103.20 & 2120.20 & 2108.80 & 16.234 & 0.504 \\
\hline & $1-42$ & 2554.60 & 2662.40 & 2681.60 & 2537.60 & 37.567 & 0.438 \\
\hline \multirow{4}{*}{$\begin{array}{c}\text { FCR/ } \\
\text { Feed: gain ratio }\end{array}$} & $1--7$ & 1.07 & 1.04 & 1.11 & 1.06 & 0.0343 & 0.912 \\
\hline & $1-21$ & 1.34 & 1.32 & 1.32 & 1.33 & 0.0098 & 0.843 \\
\hline & $1-35$ & 1.56 & 1.54 & 1.53 & 1.55 & 0.0096 & 0.697 \\
\hline & $1-42$ & 1.74 & 1.70 & 1.70 & 1.77 & 0.033 & 0.855 \\
\hline \multirow{3}{*}{ Mortality (\%) } & $1-14$ & 0.00 & 1.67 & 1.67 & 0.83 & 0.427 & 0.472 \\
\hline & $1-21$ & 0.83 & 1.67 & 1.67 & 0.83 & 0.475 & 0.560 \\
\hline & $1-42$ & 1.67 & 1.67 & 2.50 & 0.83 & 0.604 & 0.813 \\
\hline
\end{tabular}

Each value represents the mean values of 5 replicates consisting of 20 birds in each replicate pen from day 1 to 42 days; SEM= standard error of mean.

Table 5. Nitrogen $\left(\mathrm{N}_{2}\right)$, dry matter (DM) and moisture level of litter matter on day 42

\begin{tabular}{ccccccc}
\hline $\begin{array}{c}\text { Parameter } \\
(\%)\end{array}$ & \multicolumn{7}{c}{ Treatment } & & \\
\cline { 2 - 5 } & \multicolumn{1}{c}{$\mathbf{T}_{\mathbf{1}}$} & \multicolumn{1}{c}{$\mathbf{T}_{\mathbf{2}}$} & \multicolumn{1}{c}{$\mathbf{T}_{\mathbf{3}}$} & $\mathbf{T}_{\mathbf{4}}$ & Pooled SEM & P-values \\
\hline $\mathrm{N}_{2}$ & 1.48 & 1.37 & 1.42 & 1.53 & 0.0368 & 0.429 \\
$\mathrm{DM}$ & 71.75 & 67.00 & 72.90 & 72.85 & 1.7086 & 0.439 \\
Moisture & 28.25 & 33.04 & 27.10 & 27.15 & 1.7086 & 0.439 \\
\hline
\end{tabular}

Each value represents the mean values of 5 replicates consisting of 20 birds in each replicate pen from day 1 to 42 days.

However, sex and heavy weight of broiler chickens could also influence the FPD and HB incidences. Male birds are more susceptible to FPD than the females as reported by previous investigators (Harms and Simpson, 1975; Nagaraj et al., 2007). There are contradicting results in the literature on this point, no difference between sexes, or more FPD in females reported by Berg (2004) and Harms et al. (1977). The relatively high magnitude of the heritability of FPD and the low genetic correlation to body weight (BW) suggest that, it is possible to reduce susceptibility to FPD by genetic selection without negative effects on BW gain. This makes the trait more likely to be included in selection indices, which would be of benefit to broiler welfare worldwide (Kjaer et al., 2006). 

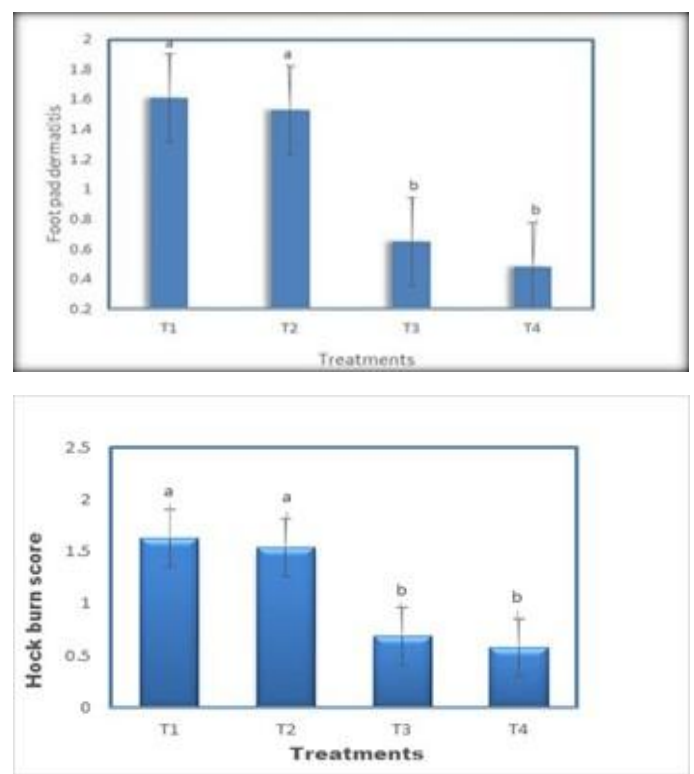

Figure 1. Foot pad dermatitis and hock burn scores of broilers of different treatments on day 42; Bars with different superscripts are significantly different at $* * P<0.01$

\section{Acknowledgement}

The authors are greatly acknowledged for the funding and contribution of ITAFos, UPM, Malaysia for conducting the project.

\section{Conclusion}

An overview of the results obtained in this current study revealed that, the growth performance of broilers and manurial value of litter materials were not affected by the litter density of wood shavings, but the incidences of leg disorders (HB and FPD) were found to reduce by using high density wood shaving in raising broiler chickens.

\section{References}

Anisuzzamaan M and SD Chowdhury (1996). Use of four types of litter for rearing broilers. British Poultry Science 37:541-545.

Bilgili SF, MA Alley, JB Hess and M Nagaraj (2006). Influence of age and sex on foot pad quality and yield in broiler chickens paw (feet) reared on low and high density diets. Journal of Applied Poultry Research 15:433441.

Brickett KE, JP Dahiya, HL Classen, C Annett and S Gomis (2007). The impact of nutrient density, feed form, and photoperiod on the walking ability and skeletal quality of broiler chickens. Poultry Science 86:2117-2125.
Berg C (2004). Pododermatitis and hock burn in broiler chickens. Measuring and Auditing Broiler Welfare. C. A. Weeks and A. Butterworth, ed. CABI Publishing, Wallingford, UK. P 37

Cervantes H (1994). Unanuevafórmula para definir la calidaddelpollito. Indústria Avícola 41:1016.

Decuypere E, K Tona and F Bruggeman (2001). The day-old chick: a crucial hinge between breeders and broilers. World's Poultry Science Journal 57:127-138.

Eichner G, SL Vieira, CA Torres, JL Coneglian, BDM Freitas and OA Oyarzabal (2007). Litter moisture and footpad dermatitis as affected by diets formulated on an allvegetable basis or having the inclusion of poultry by-product. Journal of Applied Poultry Research 16:344-350.

Fleet JC and WW Saylor (1983). Interaction of dietary electrolytes and coccidiostats in broilers. Poultry Science 62:1422-1423.

Francesch M and J Brufau (2004). Nutritional factors affecting excreta/litter moisture and quality. World's Poultry Science Journal 60:64-75.

Garcia RG, ICL Almeida Paz, FR Caldara, IA Nääs, DF Pereira, LW Freitas, AW Schwingel, NDS Lima and JD Graciano (2010). Effect of the litter material on drinking water quality in broiler production. Brazilian Journal of Poultry Science 12 165-169.

Godwin JL, Carter TA and JL Grimes (2000). The use of litter plus as a bedding material for broilers. National Poultry Waste Management Symposium; Auburn. Alabama; United State of America17:344351.

Hossain MA, AF Islam and PA Iji (2013a). Growth responses, excreta quality, nutrient digestibility, bone development and meat yield traits of broiler chickens fed on vegetable or animal protein diets. South African Journal of Animal Science 43:208218.

Hossain MA. (2013b). Improving vegetable protein diet for broiler chickens. A PhD Thesis, University of New England, NSW, Australia.

Harms RH, BL Damron and C F Simpson (1977). Effect of wet litter and supplemental biotin and/or whey on the production of foot pad dermatitis in broilers. Poultry Science 56:291-296.

Harms RH and CF Simpson (1975). Biotin deficiency as a possible cause of swelling and ulceration of foot pads. Poultry Science 54:1711-1713. 
Hossain et al. (2018) Bang. J. Anim. Sci. 47 (1):21-27

Kjaer JB, G Su, BL Nielsen and P Sørensen (2006). Foot pad dermatitis and hock burn in broiler chickens and degree of inheritance. Poultry Science 85:1342-348.

Kestin SC, G Su, and P Sorensen (1999). Different commercial broiler crosses have different susceptibilities to leg weakness. Poultry Science, 78: 1085-1090.

Murakami AE, EO Oviedo-Rondon, EN Martins, Pereira MS and Scapinello C (2001). Sodium and chloride requirements of growing broiler chickens ( 21 to 42 days of age) fed corn soybean diets. Poultry Science 80:289-294.

Mizu MMR, SD Chowdhury, MJ Karim and SC Debnath (1998). Influence of rice husk litter on broiler performance, litter dampness and its Coccidialo ocysts population during winter. Asian-Australasian Journal of Animal Science 11:450-454.

Oliveira MC, RB Gourlart and JCN Silva (2002). Efeito de duasdensidades e doistipos de camasobre a umidade da cama e a incidência de lesõesnacarcaça de frango de corte. Ciência Animal Brasileira 3:7-12.

Orban JI, O Adeola and R Stroshine (1999). Microbial phytase in finisher diets of white Pekin ducks: Effect on growth performance, plasma phosphorus concentration, and leg bone characteristics. Poultry Science 78:366-377.
Parsons AH and SL Baker (1985). Softwood chipping fines: Efficacy as poultry litter. PoultryScience 64:2292-2295.

Reed MJ and MG Mccartney (1970). Physical properties of selected litter materials and performance of broiler chickens. [research bulletin 75]. Georgia (FL): College of Agriculture Experiment Station.

Smith A, SP Rose, RG Well and V Pirgozliev. (2000). Effect of excess dietary sodium, potassium, calcium, and phosphorus on excreta moisture of laying hens. British Journal of Nutrition41:598-607.

Santos EC, AS Teixeira, DM Torres, RA Fonseca (2000). Avaliação das propriedades de quatromateriais e duasgranulometrias de camasobre o desempenho de frangos de corte: Anais da Reunião Anual da SociedadeBrasileira de Zootecnia; 2000; Viçosa, Minas Gerais. Brasil. p.48-50.

Willis WL, C Murray and C Talbott (1997). Evaluation of leaves as litter material. Poultry Science 76:1138-1140.

Zavala G (1997). Manejo de problem as locomotors en reproductor aspesadas. Avicultura Professional 15:26-28. 